\title{
Endoscopic ICG perfusion imaging for flap transplants: clinical results
}

\author{
Christian Betz \\ From 2nd Scientific Meeting of the Head and Neck Optical Diagnostics Society \\ San Francisco, CA, USA. 23-24 January 2010
}

\section{Objective}

Malfunction of microvascular anastomoses in the early postoperative period is regarded as the main reason for failure of free-tissue transfer. It was the aim of the current investigation to prove the feasibility and to explore the clinical benefit of endoscopically guided free-flap perfusion measurements in the head and neck region using red-excited indocyanine green (ICG).

\section{Methods}

A total of 25 patients who underwent major ablative surgery followed by free-flap reconstruction of the upper aerodigestive tract took part in this study. Each participant underwent three ICG-angiographies (intraoperatively, and 24 and $72 \mathrm{~h}$ postoperatively). The obtained data were evaluated both online and offline on a PC, and the results compared to the clinical outcome.

\section{Results}

There were no partial or complete losses of transplants. Two flaps with an early arterial failure were successfully salvaged by revision surgery. The ICG-angiographies were tolerated well. The gain of fluorescence was delayed in the transplanted tissue when compared to the surrounding tissue, whereas the final maximum fluorescence intensities were comparable. The two flaps with the initial compromise in perfusion showed relative fluorescence maxima (transplant vs. surrounding) of $33 \%$ or $37 \%$, respectively, whereas these values lay above $64 \%$ for all other examinations.

\section{Conclusion}

It was possible to prove the feasibility of endoscopic ICG-angiographies in patients with free-tissue transfer to the upper aerodigestive tract. The method is easy to

Ludwig-Maximilians University, Munich, Germany perform and there were no adverse events. Particularly in difficult situations, such as questionable Doppler signals, or flaps situated far down in the pharynx, the method seems to be a welcome adjunct to conventional screening.

Published: 29 October 2010

doi:10.1186/1758-3284-2-S1-015

Cite this article as: Betz: Endoscopic ICG perfusion imaging for flap transplants: clinical results. Head \& Neck Oncology 2010 2(Suppl 1):015.

Submit your next manuscript to BioMed Central and take full advantage of:

- Convenient online submission

- Thorough peer review

- No space constraints or color figure charges

- Immediate publication on acceptance

- Inclusion in PubMed, CAS, Scopus and Google Scholar

- Research which is freely available for redistribution 